\title{
Efektivitas dan Efisiensi Penyelesaian Sengketa Kekayaan Intelektual Melalui Arbitrase dan Mediasi Berdasarkan Undang-Undang Nomor 30 Tahun 1999
}

\author{
Sudjana \\ Fakultas Hukum, Universitas Padjadjaran \\ Email: sdjana@yahoo.com
}

\begin{abstract}
This review discusses the effectiveness and efficiency of dispute resolution of intellectual property through Arbitration compared to Mediation under Law Number 30 of 1999. Approach method used is normative juridical, that is studying national legislation. Specific descriptive analytical research in the sense of describing the issues discussed and analyzed. The research stage is done through literature study to examine the primary law material such as Law Number 30 of 1999 Concerning Arbitration and Alternative Dispute Resolution. Furthermore, secondary law material is done through expert opinion, and tertiary legal material is digital source (internet). Data collection techniques are conducted through document studies, which are conducted by reviewing documents on intellectual property dispute resolution. Then the method of data analysis is done through normative qualitative, it means to study the problem do not use statistic formula, but starting from the principles of law. The results of the study show that the settlement of intellectual property disputes through Arbitration and Mediation each has advantages and disadvantages. Mediation is more effective and efficient than Arbitration relating to stakeholder relations, atmosphere, results achieved, and costs. However, in terms of legal certainty, arbitration is more effective because the decision is final and binding.
\end{abstract}

Keywords: Dispute Resolution, Intellectual Property, Arbitration, Mediation.

\begin{abstract}
Abstrak
Kajian ini membahas efektivitas dan efisiensi penyelesaian sengketa kekayaan intelektual melalui Arbitrase dibandingkan dengan Mediasi berdasarkan Undang-Undang Nomor 30 Tahun 1999. Metode pendekatan yang digunakan adalah yuridis normatif, yaitu mengkaji perundangundangan nasional. Spesifikasi penelitian deskriptif analitis dalam arti menggambarkan permasalahan yang dibahas kemudian dianalisis. Tahap penelitian dilakukan melalui studi kepustakaan untuk meneliti bahan hukum primer antara lain Undang-undang Nomor 30 Tahun 1999 Tentang Arbitrase dan Alternatif Penyelesaian Sengketa, Selanjutnya bahan hukum sekunder dilakukan melalui pendapat para akhli, dan bahan hukum tersier yaitu sumber digital (internet). Teknik pengumpulan data dilakukan melalui studi dokumen, yang dilakukan dengan mengkaji dokumen-dokumen tentang Penyelesaian sengketa kekayaan Intelektual. Kemudian Metode analisis data dilakukan melalui normatif kualitatif, artinya mengkaji permasalahan tidak menggunakan rumus statistik, tetapi bertitik tolak dari prinsip-prinsip hukum. Hasil kajian menunjukan bahwa penyelesaian sengketa kekayaan intelektual melalui Arbitrase dan Mediasi masing-masing memiliki kelebihan dan kelemahan. Mediasi lebih efektif dan efisien dibandingkan Arbitrase berkaitan dengan hubungan para pihak, suasana, hasil yang dicapai, dan biaya. Namun dari sisi kepastian hukum, arbitrase lebih efektif karena putusannya bersifat final and binding.
\end{abstract}

Kata Kunci : Penyelesaian Sengketa, Kekayaan Intelektual, Arbitrase, Mediasi 


\section{PENDAHULUAN}

Salah satu tujuan Pembangunan Nasional adalah memajukan kesejahteraan umum berdasarkan Pancasila dan UndangUndang Dasar 1945 sebagaimana tercantum dalam Alinea IV Pembukaan UndangUndang Dasar Negara Republik Indonesia Tahun 1945 yang berbunyi ""Kemudian daripada itu untuk membentuk suatu pemerintah negara Indonesia..... dan untuk memajukan kesejahteraan umum........"

Pembangunan Nasional di bidang ekonomi menjadi salah satu andalan Indonesia dan berbagai negara dan berkembang sejalan dengan pesatnya ilmu pengetahuan dan teknologi menuntut perlunya memenuhi unsur pelindungan dan pengembangan ekonomi kreatif melalui lahirnya kreasi-kreasi baru dan orisinal sebagai perwujudan hasil pemikiran intelektual manusia, sehingga diharapkan kontribusi bagi perekonomian negara dapat lebih optimal. Kekayaan Intelektual (selanjutnya disebut KI) dapat memberikan kontribusi finansial karena memiliki nilai ekonomi tinggi, sehingga dapat berakibat positif bagi pertumbuhan ekonomi nasional. Pertumbuhan ekonomi yang kompleks dan sarat persaingan berpotensi terjadinya sengketa atau konflik yang memerlukan penyelesaian yang cepat, mudah, dan biaya ringan.

Penyelesaian sengketa secara konvensional dilakukan melalui pengadilan (jalur litigasi), tetapi perkembangan berikutnya timbul penyelesaian sengketa diluar pengadilan karena ketidakpuasan terhadap upaya penyelesaian sengketa melalui pengadilan. Penyelesaian sengketa di luar pengadilan dapat dilakukan melalui Arbitrase dan Alternatif Penyelesaian sengketa (APS) yaitu konsultasi, negosiasi, mediasi, konsiliasi, atau penilaian ahli sebagaimana diatur dalam Undang-undang (UU) Nomor (No) 30 Tahun 1999. Namun, yang dapat diselesaikan adalah sengketa di bidang perdagangan atau bisnis, sehingga sengketa-sengketa yang timbul bukan berkaitan dengan bisnis dan tidak dapat diadakan perdamaian bukan merupakan obyek penyelesaian UU tersebut.

Lahirnya UU No 30 Tahun 1999 berdasarkan atas penyelenggaraan kekuasaan kehakiman yang diserahkan kepada badan peradilan dengan berpedoman kepada UU No 14 Tahun 1970 Tentang Ketentuan-ketentuan Pokok Kekuasaan Kehakiman. Hal tersebut merupakan induk dan kerangka umum yang meletakkan dasar dan asas peradilan serta pedoman bagi lingkungan peradilan umum, peradilan agama, peradilan militer dan peradilan tata usaha negara yang masingmasing diatur dalam UU tersendiri. Di dalam Penjelasan Pasal 3 Ayat (1) UU No 14 Tahun 1970 disebutkan antara lain bahwa penyelesaian perkara di luar pengadilan atas dasar perdamaian atau melalui Arbitrase tetap diperbolehkan, tetapi putusan arbiter hanya mempunyai kekuatan eksekutorial setelah memperoleh izin atau perintah untuk dieksekusi (executoir) dari pengadilan. Selama ini yang dipakai sebagai dasar pemeriksaan Arbitrase di Indonesia adalah Pasal 615 sd Pasal 651 Reglemen Acara Perdata (Reglement op de Rechtsvordering, Staatsblad 1847. 52) dan Pasal 377 Reglemen Indonesia Yang Diperbaharui (Het Herzeiene Indonesisch Reglement, Staatsblad 1941:44) dan Pasal 705 Reglemen Acara Untuk Daerah Luar Jawa dan Madura (Rechtsreglement Buitengewesten, Staatsblad 1917 No 127). ${ }^{1}$

Perkembangan dunia usaha dan lalu lintas di bidang perdagangan baik nasional maupun internasional serta perkembangan hukum pada umumnya, maka peraturan yang terdapat dalam Reglemen Acara Perdata (Reglement op de Rechtvordering) yang dipakai sebagai pedoman Arbitrase sudah tidak sesuai lagi sehingga perlu disesuaikan karena pengaturan yang bersifat internasional sudah merupakan kebutuhan condido sine qua non sedangkan hal tersebut tidak diatur dalam Reglemen Acara Perdata (Reglementop de Rechtvordefing). Bertolak dari kondisi ini,

\footnotetext{
${ }^{1}$ Penjelasan Umum UU No 30 Tahun 1999.
} 
perubahan yang mendasar terhadap Reglemen Acara Perdata (Reglement op de Rechtvordering) baik secara filosofis maupun substantif sudah dilaksanakan.

Negara maju seperti Amerika memulai usaha-usaha untuk menemukan bentuk APS terjadi pada saat Warren Burger (mantan Chief of Justice ) diundang pada suatu konferensi yaitu Roscoe Pound Conference on the Causes of Popular Dissatisfaction with the Administration of Justice (Pound Conference) di Saint Paul, Minnesota. Para akademisi, pengamat hukum, serta pengacara yang menaruh perhatian pada masalah sengketa/ konflik, berkumpul bersama pada konferensi tersebut, akhirnya disusun menjadi suatu pengertian dasar (basic understanding) tentang penyelesaian sengketa saat itu. ${ }^{2}$

Perlindungan KI secara internasional diatur dalam The Berne Convention for the Protection of Literary and Artistic Works of 1886 untuk perlindungan Hak Cipta; dan Paris Convention for the Protection of Industrial Property untuk Kekayaan Perindustrian. Kemudian, lahir ketentuanketentuan internasional di bidang Hak Cipta dan Kekayaan Perindustrian lainnya yang mengacu kepada 2 (dua) perjanjian internasional tersebut. Salah satu issue dari Persetujuan Putaran Uruguay adalah aspekaspek perdagangan yang berkaitan dengan KI, yang dituangkan dalam TRIPs Agreement (Agreement on Trade Related Aspects of Intellectual Property Right) sebagai Annex dari Agreement Establishing the World Trade Organization (WTO). ${ }^{3} \mathrm{Di}$ PBB sebelum lahirnya WTO sudah

2 https://www.scribd.com/doc/231904015/Makalahtentang-Penyelesaian-Sengketa-Alternatif

${ }^{3}$ Terbentuknya TRIPs pada dasarnya merupakan dampak dari kondisi perdagangan dan ekonomi internasional yang dirasa makin mengglobal sehingga perkembangan teknologi sebagai pendukungnya tidak lagi mengenal batas-batas Negara. Lihat Rachmadi Usman, Hukum Hak Kekayaan atas Intelektual : Perlindungan dan Dimensi Hukumnya di Indonesia, Alumni, Bandung, 2003, hlm 39. mempunyai badan khusus yang menangani masalah KI yaitu World Intellectual Property Organization (WIPO), namun keberadaan WIPO dianggap kurang kuat dalam melindungi $\mathrm{KI}^{4}$

Indonesia sebagai negara yang telah meratifikasi TRIPs melalui UU No 7 Tahun 1994 Tentang Pengesahan Pembentukan Organisasi Perdagangan Dunia (World Trade Organisation/WTO), Indonesia memiliki keterikatan untuk melaksanakan ketentuanketentuan KI yang terdapat dalam TRIPs. ${ }^{5}$

Berkaitan hal itu, Indonesia telah mengesahkan dan memperbarui ketentuan yang berkaitan KI, yaitu: UU No 28 Tahun 2014 Tentang Hak Cipta; UU No 13 Tahun 2016 Tentang Paten; UU No 20 Tahun 2016 Tentang Merek dan Indikasi Geografis; UU No 29 Tahun 2000 Tentang Perlindungan Varietas Tanaman, UU No 30 Tahun 2000 Tentang Rahasia Dagang; UU No 31 Tahun

4 Kelemahan WIPO antara lain:(1). WIPO hanya merupakan suatu organisasi yang anggotanya terbatas (tidak banyak), sehingga ketentuan-ketentuannya tidak dapat diberlakukan terhadap anggotanya; (2). WIPO tidak memiliki mekanisme untuk menyelesaikan dan menghukum setiap pelanggaran KI; (3).WIPO dianggap juga tidak mampu mengadaptasi perubahan struktur perdagangan internasional dan perubahan tingkat inovasi teknologi. Lihat Fidel Djaman, Beberapa Aturan dan Kebijakan Penting di Bidang Hak Milik Intelektual, Varia Peradilan Nomor 106, Jakarta , Ikatan Hakim Indonesia sebagaimana dikutip oleh Rachmadi Usman, ibid.

5 Ratifikasi ini diikuti dengan berbagai langkah penyesuaian. Terdapat lima langkah strategis dalam rangka penyesuaian, yaitu: (1).Legislasi dan Konvensi Internasional: merevisi atau mengubah peraturan perundang-undangan yang telah ada di bidang KI dan mempersiapkan peraturan perundangundangan baru untuk bidang KI, juga mempersiapkan penyertaan Indonesia dalam konvensi-konvensi internasional; (2).Administrasi:menyempurnakan sistem administrasi pengelolaan KI dengan misi memberikan perlindungan hukum dan menggalakkan pengembangan karya-karya intelektual; (3).Kerjasama: meningkatkan kerjasama terutama dengan pihak luar negeri; (4).Kesadaran masyarakat: memasyarakatkan atau sosialisasi KI; (5).Penegakan Hukum: membantu penegakan hukum di bidang KI, Ibid. 
2000 Tentang Desain Industri; UU No 32 Tahun 2000 Tentang Desain Tata Letak Sirkuit Terpadu.

Ketentuan UU No 30 Tahun 1999

Tentang Arbitrase dan APS dapat diberlakukan untuk sengketa di luar pengadilan berkaitan dengan KI. APS menurut UU tersebut meliputi antara lain mediasi. Namun, dikenal juga mediasi di pengadilan sebagaimana diatur dalam PERMA No. 1 Tahun 2008 Tentang Prosedur Mediasi di Pengadilan. Hal itu berarti mediasi dapat dikategorikan ke dalam 2 (dua) bagian, yaitu mediasi di luar pengadilan; dan mediasi di pengadilan.

Mediasi di pengadilan diatur dengan UU No. 48 Tahun 2009 Tentang Kekuasaan Kehakiman, bahwa "Ketentuan sebagaimana dimaksud pada Ayat (1) tidak menutup usaha penyelesaian perkara perdata secara perdamaian" (Pasal 10 Ayat (2). Sedangkan mediasi di luar pengadilan, dalam UU No. 48 Tahun 2009 diatur pada Bab XII dari Pasal 58 sampai dengan Pasal 61. Empat pasal ini merujuk pada UU No. 30 Tahun 1999 Tentang Arbitrase dan APS. Menurut UU No. 48 Tahun 2009, mediasi melalui pengadilan diatur lebih lanjut dalam PERMA No. 1 Tahun 2008 Tentang Prosedur Mediasi di Pengadilan, yang ditetapkan pada tanggal 31 Juli 2008. PERMA No. 1 Tahun 2008 yang terdiri atas VIII Bab dan 27 Pasal, tidak merujuk dan tidak pula mengacu kepada UU No. 30 Tahun 1999 sebagaimana tidak ditemukannya UU No. 30 Tahun 1999 dalam Konsiderans "Mengingat" PERMA yang dimaksudkan itu. ${ }^{6}$ Dengan demikian, mediasi menurut PERMA No. 1 Tahun 2008 berbeda dengan mediasi dalam UU No 30 Tahun 1999. Mediasi dalam PERMA No. 1 Tahun 2008 dimaksudkan sebagai mediasi dalam pengadilan (litigasi) sedangkan mediasi menurut UU No 30 Tahun 1999 ditujukan

\footnotetext{
${ }^{6}$ Idris Talib, Bentuk Putusan Penyelesaian Sengketa Berdasarkan Mediasi, tersedia dalam file://C:/Users/user/AppData/Local/Temp/12952482-1-SM.pdf
}

untuk penyelesaian sengketa di luar pengadilan (non litigasi).

Mekanisme penyelesaian sengketa diluar pengadilan menurut UU No 30 Tahun 1999 ada beberapa bentuk, tetapi kajian ini akan membahas penyelesaian sengketa berkaitan dengan KI melalui arbitrase dan mediasi dengan fokus analisis pada efektivitas dan efisiensi kedua mekanisme tersebut melalui metode perbandingan. Berdasarkan hal itu, maka identifikasi masalahnya adalah:" Bagaimana efektivitas dan efisiensi Penyelesaian Sengketa KI melalui Arbitrase dibandingkan dengan Mediasi berdasarkan Undang-Undang Nomor 30 Tahun 1999.”

\section{PEMBAHASAN}

Efektivitas (kata sifat) memiliki arti berhasil atau tepat guna yang berasal dari kata dasar "efektif." Efektivitas menunjukkan keberhasilan dari segi tercapai tidaknya sasaran yang telah ditetapkan. Menurut Kamus Besar Bahasa Indonesia, kata efektif mempunyai arti efek, pengaruh, akibat atau dapat membawa hasil. Jadi, efektivitas adalah keaktifan, daya guna, adanya kesesuaian dalam suatu kegiatan orang yang melaksanakan tugas dengan sasaran yang dituju. $^{7}$ Efektivitas pada dasarnya menunjukkan pada taraf tercapainya hasil, sering atau senantiasa dikaitkan dengan pengertian efisien, meskipun sebenarnya ada perbedaan diantara keduanya. Efektivitas menekankan pada hasil yang dicapai, sedangkan efisiensi lebih melihat pada bagaimana cara mencapai hasil yang dicapai itu dengan membandingkan antara input dan outputnya (penulis: asas hemat). Dengan demikian, secara singkat pengertian efisiensi berarti melakukan atau mengerjakan sesuatu secara benar, "doing things right", sedangkan efektivitas melakukan atau mengerjakan

\footnotetext{
${ }^{7}$ http://literaturbook.blogspot.co.id/2014/12/pengertianefektivitas-dan-landasan.html
} 
sesuatu tepat pada sasaran "doing the right things."

Istilah "Sengketa" atau Disputes (bahasa Inggris), seringkali disebut sama dengan "Konflik" atau Conflict (bahasa Inggris). Henry Campbell Black menjelaskan arti "Dispute", sebagai: "A conflict of controversy; a conflict of claims or rights; an assentation of a right, claim, or demand on one side, met by contrary claims or allegations on the other. The subject of litigation; the matter for which a suit is brought and upon which issue is joined, and in relation to which jurors are called and witnesses examined."

Dalam literatur, Teori Persengketaan juga dinamakan dengan Teori Konflik. Pengertian Konflik dirumuskan oleh Dean G. Pruitt dan Jeffrey Z. Rubin, konflik adalah persepsi mengenai perbedaan kepentingan (perceived divergence of interest), atau suatu aspirasi pihak-pihak yang berkonflik tidak dicapai secara simultan (secara serentak). ${ }^{10}$ Pruitt dan Rubin lebih lanjut melihat konflik dari perbedaan kepentingan atau tidak dicapainya kesepakatan para pihak. Maksud Perbedaan kepentingan adalah berlainannya keperluan atau kebutuhan masing-masing pihak. Selanjutnya, Teori Konflik menurut Salim HS, dapat digolongkan atas: a. Objek kajiannya; b. Faktor penyebab terjadinya konflik; dan c. Strategi dalam penyelesaian konflik. ${ }^{11}$ Takdir Rahmadi, mengemukakan beberapa teori konflik, salah satunya adalah Teori kebutuhan atau kepentingan manusia, yang intinya teori ini mengungkapkan bahwa konflik dapat terjadi karena kebutuhan atau kepentingan manusia tidak dapat terpenuhi atau merasa dihalangi oleh pihak lain. ${ }^{12}$

http://elib.unikom.ac.id/files/disk1/456/jbptunikompp -gdl-iiphimawan-22764-7-babii.pdf

9 Henry Campbell Black, Black's Law Dictionary, West Publishing Co., St. Paul, 1989, page. 424

10 Salim HS, op cit, hlm.82. Lihat juga Idris Talib, loc.cit.

${ }^{11}$ Ibid, hlm. 85

12 Selengkapnya lihat Takdir Rahmdi dalam http://eprints.uny.ac.id/ 22029/4/4.BAB\% 20II.pdf
Pihak-pihak yang bersengketa dalam praktik dapat melakukan beberapa pendekatan dalam mengelola sengketa yang dihadapi. Secara umum ada beberapa pendekatan pengelolaan konflik atau sengketa yang terjadi, yaitu ${ }^{13}$ a. Power Based, merupakan pendekatan pengelolaan sengketa dengan mendasarkan pada kekuatan atau kekuasaan untuk memaksa seseorang untuk berbuat sesuatu atau tidak berbuat sesuatu. Pendekatan ini umumnya dilakukan apabila satu pihak memiliki posisi dan akses yang lebih kuat dari pihak yang lain; b. Right Based, adalah pendekatan dengan mendasarkan konsep hak (hukum), yaitu konsep benar dan salah berdasarkan parameter yuridis melalui prosedur adjudikasi, baik di pengadilan maupun arbitrase. Pencari keadilan yang ingin menyelesaikan sengketanya harus terlebih dahulu mengajukan perkaranya ke pengadilan atau melalui arbitrase. ${ }^{14}$ Pendekatan seperti ini umumnya mengarah pada keadaan winlose solution, yaitu ada pihak yang dimenangkan dan ada pula pihak yang dikalahkan di sisi lainnya; c. Interest Based, merupakan pendekatan dengan mendasarkan pada kepentingan pihak- pihak yang bersengketa, bukan pada posisi masingmasing sehingga mencerminkan kepentingan

13 Bambang Sutiyoso, Hukum Arbitrase dan Penyelesaian Sengketa, Gama Media, Yogja- karta, 2008,hlm 8 http://ilib.usm.ac.id/sipp/doc/jurnas/gdlusm--dewitutimu-87-1-pengatur-e.pdf

${ }^{14}$ Penyelesaian sengketa melalui pengadilan memiliki sanksi hukum yang bersifat otonom, sedangkan penyelesaian sengketa di luar pengadilan, sanksinya bersifat heteronom. Bersifat otonom, oleh karena upaya paksa jika putusan pengadilan tidak dilaksanakan oleh para pihak, ada pada lembaga peradilan (Peradilan Umum), antara lainnya melalui aparat penegak hukum, lembaga pemasyarakatan, dan lain-lainnya. Penyelesaian sengketa di luar pengadilan bersifat heteronom dalam penegakan hukumnya, oleh karena putusan arbitrase maupun putusan alternatif penyelesaian sengketa membutuhkan penguatannya lebih lanjut melalui lembaga peradilan. Hal ini berarti Ada pihak lain yang turut menguatkan kekuatan hukum memaksa dari putusan arbitrase dan alternatif penyelesaian sengketa. Idris Talib, ibid. 
yang bersengketa secara mutual (win-win solution).

Arbitrase secara umum dapat dilakukan dalam penyelesaian sengketa publik maupun perdata, tetapi dalam perkembangannya arbitrase lebih banyak dipilih untuk menyelesaikan sengketa kontraktual (perdata), yang diklasifikasikan menjadi: ${ }^{15}$ (1), Quality arbitration, yang menyangkut permasalahan faktual (question of fact) yang memerlukan para arbiter dengan kualifikasi teknis yang tinggi; (2). Technical arbitration, yang tidak menyangkut permasalahan faktual, sebagaimana halnya dengan masalah yang timbul dalam dokumen (construction of document) atau aplikasi ketentuan-ketentuan kontrak; (3). Mixed arbitration, sengketa mengenai permasalahan faktual dan hukum (question of fact and law).

Metode penyelesaian sengketa di luar pengadilan berkaitan dengan KI secara internasional dilakukan oleh organisasi internasional (specialized agency) PBB yang bernama WIPO (World Intellectual Property Organization). WIPO menyediakan 4 prosedur untuk menyelesaikan sengketa, yaitu: a. Mediation Rules; b.Arbitration Rules; c.Arbitrase secara "dipercepat" (Expedit ed Arbitration Rules); d.Med-Arb, yaitu prosedur secara kombinasi dari mediasi yang diikuti oleh arbitrase sesuai ketentuan arbitrase dari WIPO apabila mediasi ini tidak berhasil. ${ }^{16}$

Penyelesaian sengketa KI melalui Arbitrase dan Mediasi dapat diajukan melalui Badan Arbitrase dan Mediasi KI (BAM KI) yang sudah terbentuk sejak tahun 2011 tetapi ternyata belum berjalan efektif padahal penyelesaian sengketa melalui BAM KI memiliki keuntungan antara lain perkara itu tertutup untuk umum, sehingga kasus tersebut tidak akan terekspos ke luar. Selain itu, jangka waktu penyelesaian dibatasi selama

\footnotetext{
15 http://www.kesimpulan.com/2009/04/alternatifpenyelesaian-sengketa.html

${ }^{16} \mathrm{http}: / /$ mahendraputra.net/wpcontent/uploads/2012/09/Bahan-Kuliah-AlternatifPenyelesaian- Sengketa-Dagang-12.pdf
}

180 hari. Artinya, selama dalam kurun waktu itu, perkara yang ditangani oleh BAM KI sudah harus diputus oleh Majelis Arbiter. ${ }^{17}$ Selain itu, menurut Zen Umar Purba prosedurnya sederhana dan biaya relatif lebih murah serta putusan bersifat final dan mengikat para pihak yang bersengketa. ${ }^{18}$

Substansi UU No 30 Tahun 1999 hampir keseluruhan isinya mengatur mengenai Arbitrase, sedangkan pengaturan mengenai APS atau Alternative Dispute Resolution (ADR) tidak djelaskan secara detail. Ketentuan APS/ADR hanya tercantum dimuat dalam Pasal 1 Angka 10 (definisi) dan Pasal 6. Mekanisme APS lainnya seperti konsultasi, negosiasi, mediasi, konsiliasi, atau penilaian ahli sangat sumir dimuat dalam UU tersebut. Bahkan Dalam Ketentuan Umum, pengertian dari masingmasing mekanisme APS tersebut juga tidak dijelaskan, hanya istilah Arbitrase yang didefinisikan secara tegas. Sedangkan istilah untuk mekanisme APS lainnya tidak ada penjelasan hanya dicantumkan sebagai bagian dari APS sebagaimana tersurat dalam Pasal 1 Angka 10 UU tersebut.

Arbitrase yaitu "cara penyelesaian suatu sengketa perdata di luar peradilan umum yang didasarkan pada perjanjian arbitrase yang dibuat secara tertulis oleh para pihak yang bersengketa." ${ }^{19}$ Menurut Black's Law Dictionary:

"Arbitration : The reference of a dispute to an impartial (third) person chosen by the Parties to the dispute who agree in advanceto abide by the arbitrator's award issued after hearing at which both parties have an oportunity to be heard. An arrangement for taking and abidingby the judgement of selected persons in some dispute metter, instead of carrying it to

\footnotetext{
${ }^{17} \mathrm{http}: / / \mathrm{www} \cdot$ patenindonesia.com/?p=682

18 Zen Umar Purba, Peranan BAM HKI dalam Penyelesaian Permasalahan Lembaga Manajemen Kolektif, Seminar

${ }^{19}$ Pasal 1 Angka 1 UU No 30 Tahun 1999.
} 
astablish tribunals of justice, and is intended to avoid the formalities, the delay, the expense and vexation of ordinary litigation."

Pada dasarnya Arbitrase dapat berwujud dalam 2 (dua) bentuk, yaitu: ${ }^{20}$ klausula arbitrase yang tercantum dalam suatu perjanjian tertulis yang dibuat para pihak sebelum timbul sengketa (factum de compromitendo); atau perjanjian Arbitrase tersendiri yang dibuat para pihak setelah timbul sengketa (akta kompromis). Dengan demikian, penyelesaian sengketa melalui arbitrase dapat secara tegas dicantumkan sebelum sengketa terjadi atau diusulkan pada saat terjadinya sengketa berdasarkan kesepakatan.

Istilah "Mediasi" dalam bahasa Inggris dinamakan "Mediation" yang diartikan oleh Munir Fuady sebagai "suatu proses penyelesaian sengketa berupa negosiasi untuk memecahkan masalah melalui pihak luar (ketiga) yang netral (mediator) dan tidak memihak, untuk membantu menemukan solusi dalam menyelesaikan sengketa tersebut secara memuaskan kedua belah pihak. ${ }^{21}$

Menurut "Black's Law Dictionary", mediasi diartikan sebagai proses penyelesaian sengketa secara pribadi, informal yaitu seorang pihak yang netral (mediator),

${ }^{20}$ Budhy Budiman. Mencari Model Ideal penyelesaian Sengketa, Kajian Terhadap praktik Peradilan Perdata dan Undang-Undang Nomor 30 Tahun 1999 tersedia dalam .http://www.uikabogor.ac.id/jur05.htm.

21 Munir Fuady, Pengantar Hukum Bisnis, Menata Bisnis Modern di Era Global, op cit, hlm. 314 sebagiaman dikutip oleh Idris Talib, ibid. Sedangkan Christopher W. Moore mengemukakan bahwa mediasi adalah intervensi dalam sebuah sengketa oleh pihak ketiga yang dapat diterima pihak yang bersengketa, bukan merupakan bagian dari kedua belah pihak dan bersifat netral. Pihak ketiga ini tidak mempunyai wewenang untuk mengambil keputusan dan bertugas untuk membantu pihak-pihak yang bertikai agar secara sukarela mau mencapai kata sepakat yang diterima oleh masing-masing pihak dalam sebuah persengketaan. Lihat Bambang Sutiyoso, Hukum Arbitrase dan Alternatif Penyelesaian Sengketa , 2008, Gama Media, Yogyakarta, hlm. 56. membantu para pihak yang bersengketa untuk mencapai kesepakatan. Mediator tidak mempunyai wewenang untuk menetapkan keputusan bagi para pihak. Mediator bersifat netral dan tidak memihak yang tugasnya membantu para pihak yang bersengketa untuk mengindentifikasikan isu-isu yang dipersengketakan mencapai kesepakatan. Dalam fungsinya mediator tidak mempunyai kewenangan untuk membuat keputusan. ${ }^{22}$ Berbeda dengan arbitrase yang mengikat dan berkekuatan eksekutorial, produk hukum dari suatu proses mediasi adalah kesepakatan para pihak yang berbentuk perjanjian, sehingga produk dari mediasi tersebut tidak memiliki kekuatan eksekutorial. ${ }^{23}$

Pada dasarnya penyelesaian sengketa melalui mediasi memiliki karakteristik atau unsur-unsur sebagai berikut: ${ }^{24}$ (1). Mediasi adalah proses penyelesaian sengketa di luar pengadilan berdasarkan perundingan; (2). Mediator terlibat dan diterima oleh para pihak yang bersengketa di dalam perundingan; (3).Mediator bertugas membantu para pihak yang bersengketa untuk mencari penyelesaian (4). Mediator bersifat pasif hanya berfungsi sebagai fasilitator dari para pihak yang bersengketa, sehingga tidak terlibat dalam menyusun dan merumuskan rancangan atau proposal kesepakatan; (5). Mediator tidak mempunyai kewenangan membuat keputusan selama perundingan berlangsung; (6). Tujuan mediasi adalah untuk mencapai atau menghasilkan kesepakatan yang dapat diterima pihak-pihak yang bersengketa guna mengakhiri sengketa.

Penyelesaian sengketa KI melalui Arbitrase dan APS diatur sesuai dengan ketentuan masing-masing yang mengatur $\mathrm{KI}$ itu sendiri, untuk Hak Cipta diatur dalam Pasal 95 UU No. 28 Tahun 2014; Paten

22 http://www.ekomarwanto.com/2011/05/arbitrasedan-alternatif-penyelesaian.html

23 Frans Hendra Winarta, Hukum Penyelesaian Sengketa: Arbitrase Nasional Indonesia dan Internasional, Sinar Grafika, Jakarta, 2013, hlm. 17

24 Suyud Margono, Penyelesaian Sengketa Bisnis : Alternative Dispute Resolution (ADR), Ghalia Indonesia, Ciawi-Bogor, 2010, hlm 54-55. 
tercantum dalam Pasal 153 UU No 13 Tahun 2016; Merek diatur dalam Pasal 93 UU No 20 Tahun 2016, Rahasia Dagang tercantum dalam Pasal 12 UU No 30 Tahun 2000, Desain Industri diatur dalam Pasal 47 UU No 31 Tahun 2000, Perlindungan Varietas Tanaman tidak tercantum secara tegas ${ }^{25}$, hanya ada pencatuman "hak menuntut" dalam Pasal 66 sd Pasal 69 UU No 29 Tahun 2000, dan Desain Tata Letak Sirkuit Terpadu diatur dalam Pasal 39 UU No 32 Tahun 2000.

\section{Penyelesaian sengketa Intelektual Melalui Arbitrase}

Kekayaan

Penyelesaian sengketa

melalui

Arbitrase timbul karena adanya kelemahan pada mekanisme penyelesaian sengketa secara litigasi dan keunggulan pada penyelesaian non litigasi. Karakteristik penyelesaian sengketa melalui sistem litigasi : a) Prosesnya sangat formal; b) Keputusan dibuat oleh pihak ketiga yang ditunjuk oleh negara (hakim); c) Para pihak tidak terlibat dalam pembuatan keputusan; d) Sifat keputusan memaksa dan mengikat (coercive and binding); e) Orientasi ke pada fakta hukum (mencari pihak yang bersalah); f) Persidangan bersifat terbuka.

Sujud Margono ${ }^{26}$ merangkum beberapa kritikan terhadap peradilan dari beberapa negara yaitu: penyelesaian sengketa "lambat" atau waste of time ${ }^{27}$; biaya perkara"mahal"28;

25 Namun juga tidak ada ketentuan yang melarang penyelesaian sengketa varietas tanaman melalui metode ADR. karena itu dapat ditafsirkan bahwa metode ADR dimungkinkan dipakai dalam penyelesaian sengketa varietas tanaman. Lihat http://mahendraputra.net/wp-

content/uploads/2012/09/Bahan-Kuliah-Alternatif-

Penyelesaian-Sengketa-Dagang -12.pdf.

26 Sujud Margono, ADR dan ARBITRASE (Proses Pelembagaan dan Aspek Hukum), Penerbit Ghalia, Bogor Selatan: Indonesia. 2004, hlm. 66.

27 a. Proses pemeriksaan bersifat sangat formal (formalistic) dan sangat teknis (technically); b. Peradilan dijejali beban yang terlampau banyak (overloaded).

28 Biaya perkara yang mahal membuat orang berperkara di pengadilan menjadi terkuras segala peradilan tidak tanggap (unresponsive) ${ }^{29}$; putusan pengadilan tidak menyelesaikan masalah. ${ }^{30}$

Penjelasan Umum UU No 30 Tahun 1999 menyebutkan keunggulan arbitrase, yaitu : kerahasiaan sengketa para pihak terjamin; keterlambatan yang diakibatkan karena hal prosedural dan administratif dapat dihindari; para pihak dapat memilih arbiter yang berpengalaman, memiliki latar belakang yang cukup mengenai masalah yang disengketakan, serta jujur dan adil; para pihak dapat menentukan pilihan hukum untuk penyelesaian masalahnya; para pihak dapat memilih tempat penyelenggaraan arbitrase ;putusan arbitrase merupakan putusan yang mengikat para pihak melalui prosedur sederhana ataupun dapat langsung dilaksanakan. ${ }^{31}$

Penafsiran sistematis terhadap Pasal 1 Angka 1 dikaitkan dengan Pasal 1 Angka 10 UU No 30 Tahun 1999 menunjukan bahwa Arbitrase dan APS adalah dua hal berbeda yang masing-masing berdiri sendiri. Dalam Pasal 1 Angka 1 UU No. 30 Tahun 1999, dijelaskan pengertian Arbitrase Sedangkan

sumber daya, waktu, dan pikiran (litigation paralyzed people).

29 a.Pengadilan kurang melindungi kepentingan umum; b. Pengadilan dianggap sering berlaku tidak adil atau unfair.

${ }^{30}$ a. Salah satu pihak menang dan pihak lain kalah (win-lose); b.Keadaan kalah menang dalam berperkara tidak membawa kedamaian tetapi menumbuhkan dendam ; c Putusan pengadilan membingungkan;d. Putusan pengadilan sering tidak memberikan kepastian hukum (uncertainty) dan tidak dapat dipredikasi (unpredictable); e.Kemampuan para hakim bersifat "generalis."

${ }^{31}$ Sejalan dengan hal itu, menurut Subekti bagi dunia perdagangan atau bisnis, penyelesaian sengketa lewat arbitrase atau perwasitan, mempunyai beberapa keuntungan yaitu bahwa dapat dilakukan dengan cepat, oleh para ahli, dan secara rahasia. Lihat Budhy Budiman, Mencari Model Ideal Penyelesaian Sengketa, Kajian Terhadap Praktik Peradilan Perdata dan Undang-Undang Nomor 30 Tahun 1999, tersedia dalam http://www.uika-bogor.ac.id/ jur05.htm. Lihat juga http:// repository. unhas.ac.id/ bitstream/handle/ 123456789/13835/Skrispi\% 20Zulkarnaen\%20

Hamka\%20b11107950.pdf?sequence=1 
dalam Pasal 1 angka 10 dinyatakan bahwa “ APS adalah lembaga penyelesaian sengketa atau beda pendapat melalui prosedur yang disepakati para pihak, yakni penyelesaian di luar pengadilan dengan cara konsultasi, negosiasi, mediasi, konsiliasi, atau penilaian ahli." Dengan demikian, Arbitrase merupakan suatu proses tersendiri yang secara tegas dibedakan dari APS. ${ }^{32}$

Penyelesaian sengketa melalui Arbitrase hanya bermanfaat untuk para pihak atau pengusaha yang bonafide (bonafid) atau jujur dan dapat dipercaya. Para pihak yang bonafid yaitu memiliki kredibilitas dan integritas, artinya patuh terhadap kesepakatan, pihak yang dikalahkan harus secara sukarela melaksanakan putusan arbitrase. Sebaliknya, jika mencari peluang untuk menolak melaksanakan putusan arbitrase, perkara melalui arbitrase justru akan memakan lebih banyak biaya, bahkan lebih lama daripada proses di Pengadilan. Misalnya, pengusaha yang dikalahkan tidak setuju dengan suatu putusan arbitrase, maka dapat melakukan berbagai cara untuk mendapatkan stay of execution (penundaan pelaksanaan putusan) dengan membawa perkaranya ke pengadilan karena alasan tertentu. ${ }^{33}$ Adanya campur tangan pengadilan negeri pada dasarnya kompetensi absolut penyelesaian sengketa arbitrase menjadi tidak efisien, sehingga menghilangkan esensi arbitrase sebagai mekanisme penyelesaian sengketa yang lebih cepat, murah, dan proses yang sederhana dibanding proses penyelesaian sengketa

\footnotetext{
${ }^{32}$ Ibid.

33 Terhadap putusan arbitrase para pihak dapat mengajukan permohonan pembatalan kepada Panitera Pengadilan negeri, apabila putusan tersebut diduga mengandung unsur-unsur sebagai berikut : a. surat atau dokumen yang diajukan dalam pemeriksaan, setelah putusan dijatuhkan, diakui palsu atau dinyatakan palsu; b. setelah putusan diambil ditemukan dokumen yang bersifat menentukan, yang disembunyikan oleh pihak lawan ; atau c. putusan diambil dari hasil tipu muslihat yang dilakukan oleh salah satu pihak dalam pemeriksaan sengketa. Lihat Pasal 70 UU No 30 Tahun 1999.
}

melalui pengadilan (litigasi). ${ }^{34}$ Dengan demikian menurut penulis, ketentuan tentang pembatalan putusan arbitrase seharusnya langsung kasasi ke MA tidak ke Pengadilan negeri agar tidak counter productive (kontra produktif) dengan tujuan UU No. 30 Tahun 1999. ${ }^{35}$

Mekanisme penyelesaian sengketa dengan arbitrase pada hakekatnya secara umum tidak jauh berbeda dengan proses pemeriksaan perkara di pengadilan, karena baik arbitrase maupun litigasi sama-sama merupakan mekanisme adjudikatif, yaitu ${ }^{36}$ pihak ketiga yang dilibatkan dalam penyelesaian sengketa tersebut sama-sama mempunyai kewenangan memutuskan sengketa tersebut. Arbitrase termasuk adjudikatif privat sedangkan litigasi termasuk adjudikatif publik, sehingga baik arbitrase maupun litigasi sama-sama bersifat win-lose solution.

Berdasarkan UU No. 30 Tahun 1999, pada prinsipnya mekanisme penyelesaian sengketa dengan arbitrase adalah melalui tiga tahapan, yaitu : tahap persiapan atau pra pemeriksaan, tahap pemeriksaan atau penentuan dan tahap pelaksanaan. Tahap persiapan adalah tahap untuk mempersiapkan segala sesuatunya guna sidang pemeriksaan perkara. Tahap persiapan antara lain meliputi:1) Persetujuan arbitrase dalam dokumen tertulis; 2) Penunjukan arbiter; 3) Pengajuan surat tuntutan oleh pemohon; 4) Jawaban surat tuntutan oleh termohon; 5) Perintah arbiter agar para pihak menghadap sidang arbitrase. Tahap kedua adalah tahap pemeriksaan, yaitu tahap mengenai jalannya sidang pemeriksaan perkara, mulai dari awal pemeriksaan peristiwanya, proses pembuktian, sampai dijatuhkannya putusan oleh arbiter. Selanjutnya adalah tahap

\footnotetext{
${ }^{34}$ Lihat Ketentuan Pasal 71 dan 72 UU No 30 Tahun 1999 menjelaskan tentang proses pembatalan putusan Arbitrase yang memakan waktu 90 hari.

35 Bandingkan pendapat yang tercantum dalam http://kilometer25. blogspot.co.id/ 2012/11/arbitrasedan-alternatif-penyelesaian.html

36 http://ilib.usm.ac.id/sipp/doc/jurnas/gdl-usm-dewitutimu-87-1-pengatur-e.
} 
pelaksanaan sebagai tahap terakhir, yaitu tahap untuk merealisasi putusan arbiter yang bersifat final dan mengikat. Pelaksanaan putusan dapat dilakukan secara sukarela maupun dengan paksa melalui eksekusi oleh Pengadilan Negeri.

\section{Penyelesaian sengketa Intelektual Melalui Mediasi}

Kekayaan

Penyelesaian sengketa melalui mediasi juga memiliki beberapa tahapan yang harus dilalui. Menurut Jacqueline M. \& NolanHaley ada beberapa tahapan yang harus dilakukan dalam mediasi, yaitu : (1) screening; (2) mediator describes process and role of mediator; (3) mediator assists parties in drafting agreement ${ }^{37}$

Peran yang lemah mediator dalam mediasi: 38 1) Penyelenggara pertemuan; 2) Pemimpin diskusi netral; 3) Penjaga aturan agar proses perundingan berlangsung secara beradab; 4) Pengendali emosi para pihak; 5) Pendorong pihak/ perunding yang kurang mampu atau segan mengemukakan pandangannya. Sedangkan peran yang kuatnya adalah: 1) Mempersiapkan dan membuat notulen perundingan; 2) Merumuskan kesepakatan para pihak; membantu para pihak agar menyadari, bahwa sengketa bukan sebuah pertarungan untuk dimenangkan, tetapi diselesaikan; 3) Menyusun dan mengusulkan alternatif pemecahan masalah; 4) Membantu para pihak menganalisis alternatif pemecahan masalah.

Menurut Fuller ${ }^{39}$ sebagaimana dikutip oleh Suyud Margono, menyebutkan 7 (tujuh) fungsi mediator, yakni : katalisator $(\text { catalyst })^{40} ; \quad$ pendidik $\quad(\text { educator })^{41}$;

37 Suyud Margono, hlm 53-54 sebagaimana dikutip oleh http://ilib.usm.ac.id// sipp/doc/jurnas/gdl-usm-dewitutimu-87-1-pengatur-e.pdf

${ }^{38}$ Ibid, hlm 55.

${ }^{39} \mathrm{Ibid}$, hlm 56.

40 Mediator dalam proses perundingan mampu mendorong lahirnya suasana yang konstruktif.

${ }^{41}$ Mediator harus memahami aspirasi, prosedur kerja, keterbatasan politis dan kendala usaha para pihak. Karena itu, harus berusaha melibatkan diri dalam dinamika perbedaan diantara para pihak.

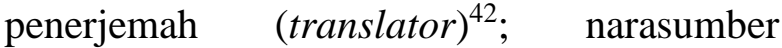
(resource person $)^{43}$; penyandang berita jelek (bearer of bad news) (4) $^{4}$ agen realitas (agent of reality) ${ }^{45}$; kambing hitam (scapegoat). ${ }^{46}$

Mediasi sebagai bentuk penyelesaian sengketa memiliki kekuatan-kekuatan sehingga mediasi menjadi salah satu pilihan yang dapat dimanfaatkan oleh pihak yang bersengketa, yaitu. ${ }^{47}$

a. Keluwesan atau fleksibilitas dibandingkan dengan proses litigasi, merupakan unsur yang menjadi daya tarik karena para pihak dapat segera membahas masalah-masalah substansial, dan tidak terperangkap dalam membahas atau memperdebatkan hal-hal teknis hukum;

b. Pada umumnya diselenggarakan secara tertutup atau rahasia. Artinya hanya para pihak dan mediator yang menghadiri proses mediasi, sedangkan pihak lain tidak diperkenankan. Kerahasiaan ini menjadi daya tarik bagi kalangan tertentu terutama pengusaha, yang tidak menginginkan masalahnya dipublikasikan;

c. Para pihak dalam proses mediasi dapat menggunakan bahasa seharihari yang lazim digunakan, tidak perlu menggunakan istilah-istilah

\footnotetext{
42 Menyampaikan dan merumuskan usulan pihak yang satu kepada pihak lainnya melalui bahasa atau ungkapan yang dimengerti, tanpa mengurangi sasaran yang dicapai oleh pengusul.

43 Mendayagunakan sumber-sumber informasi yang tersedia

${ }^{44}$ Mediator menyadari bahwa para pihak dalam proses perundingan dapat bersikap emosional, maka mediator harus mengadakan pertemuan terpisah dengan pihak-pihak untuk menam-pung berbagai usulan.

${ }^{45}$ Memberi pengertian secara jelas kepada salah satu pihak bahwa sasarannya tidak mungkin/ tidak masuk akal untuk dicapai melalui perundingan.

46 Mediator harus siap disalahkan, misalnya dalam membuat kesepakatan hasil perundingan.

${ }^{47}$ Takdir Rahmadi sebagaimana dikutip dalam http://eprints.uny.ac.id/ 22029/4/4.BAB\%20II.pdf
} 
hukum seperti yang digunakan oleh advokat dalam beracara di pengadilan;

d. Para pihak dalam proses mediasi dapat membahas berbagai aspek atau berbagai sisi dari perselisihannya, tidak hanya aspek hukum;

e. Sesuai sifatnya yang konsensual atau mufakat dan kolaboratif, mediasi dapat menghasilkan penyelesaian menang-menang bagi para pihak (win-win solution). Sebaliknya, litigasi dan arbitrase cenderung menghasilkan penyelesaian menangkalah (win-lose solution);

f. Mediasi merupakan proses penyelesaian sengketa yang relatif murah dan tidak makan waktu jika dibandingkan dengan proses litigasi.

Selain memiliki kelebihan, mediasi juga memiliki beberapa kelemahan, antara lain $:^{48}$

a. Mediasi hanya dapat diselenggarakan secara efektif jika para pihak memiliki kemauan untuk menyelesaikan sengketa secara konsensus. Jika hanya salah satu pihak saja yang memiliki keinginan, sedangkan pihak lawannya tidak memiliki keinginan yang sama, maka mediasi tidak akan terjadi dan jikapun terlaksana tidak berjalan efektif;

b. Pihak yang tidak beriktikad baik dapat memanfaatkan proses mediasi sebagai taktik untuk mengulur-ulur waktu penyelesaian sengketa, misalnya dengan tidak mematuhi jadwal sesi-sesi mediasi atau berunding sekedar untuk memperoleh informasi tentang kelemahan lawan;

c. Beberapa jenis kasus mungkin tidak dapat dimediasi, terutama kasuskasus yang berkaitan dengan masalah ideologis dan nilai dasar

\footnotetext{
${ }^{48}$ Ibid.
}

yang tidak menyediakan ruang bagi para pihak untuk melakukan kompromi;

d. Mediasi tidak tepat untuk digunakan jika masalah pokok dalam sengketa adalah soal penentuan hak karena harus diputus oleh hakim, sedangkan mediasi lebih tepat untuk digunakan menyelesaikan sengketa terkait dengan kepentingan;

e. Secara normatif mediasi hanya dapat ditempuh atau digunakan dalam lapangan hukum privat dan tidak dalam lapangan hukum bersifat memaksa.

Faktor-faktor yang mendorong para pihak menempuh mediasi: ${ }^{49}$ a. Pandangan teoritis pertama merujuk pada kebudayaan sebagai faktor dominan. Berdasarkan pandangan ini, cara-cara penyelesaian konsensus dapat diterima karena pendekatan itu sesuai dengan cara pandang kehidupan masyarakat yang mewarisi tradisi kebudayaan yang menekankan keharmonisan dan kebersamaan; b.Pandangan teoritis kedua lebih melihat kekuatan (power) yang dimiliki oleh para pihak yang bersengketa sebagai faktor dominan. Menurut pandangan ini, orang bersedia untuk menempuh mediasi lebih disebabkan oleh adanya kekuatan (power) para pihak yang relatif seimbang. Pihak-pihak bersedia menempuh perundingan bukan karena terikat nilai budaya atau nilai spiritual tetapi karena membutuhkan kerjasama agar dapat mencapai tujuannya atau mewujudkan kepentingannya.

Secara garis besar dapat dikemukakan tahapan-tahapan mediasi sebagai berikut $:^{50} 1$ ) Tahap pertama, pembentukan forum. Pada awal mediasi, sebelum rapat antara mediator dan para pihak, mediator membentuk forum, selanjutnya, Mediator memberitahukan kepada para pihak mengenai bentuk dari proses; aturan dasar; bekerja berdasarkan

\footnotetext{
${ }^{49}$ http://eprints.uny.ac.id/22029/4/4.BAB\%20II.pdf

50 http://ilib.usm.ac.id/sipp/doc/jurnas/gdl-usm-dewitutimu-87-1-pengatur-e.pdf
} 
hubungan dengan para pihak dan mendapat kepercayaan sebagai pihak netral; melakukan negosiasi mengenai wewenangnya dengan para pihak dan menjawab pertanyaan para pihak; apabila sepakat melanjutkan perundingan, para pihak diminta komitmen untuk mentaati aturan yang berlaku; 2) Tahap kedua, Pengumpulan dan pembagian informasi. Setelah tahap awal selesai, maka mediator meneruskannya dengan mengadakan rapat bersama, dengan meminta penjelasan pendahuluan dari masing-masing pihak yang bersengketa. Pada tahap informasi, para pihak dan mediator saling membagi informasi. Apabila para pihak setuju meneruskan mediasi, mediator kemudian mempersilakan masing-masing pihak menyajikan versinya mengenai fakta dan patokan yang diambil dalam sengketa tersebut. Mediator boleh mengajukan pertanyaan untuk mengembangkan informasi, tetapi dapat tidak mengijinkan pihak lain untuk mengajukan pertanyaan atau melakukan interupsi. Mediator harus melakukan kualifikasi fakta yang telah disampaikan, karena fakta yang disampaikan para pihak merupakan kepentingan-kepentingan yang dipertahankan oleh masing-masing pihak agar pihak lain menyetujuinya. Kemudian dilanjutkan dengan diskusi terhadap informasi yang disampaikan oleh masing-masing pihak, untuk mengukuhkan bahwa mediator telah mengerti dan secara netral membuat kesimpulan atas penyajian masing-masing pihak, mengulangi fakta-fakta esensial menyangkut setiap perspektif atau patokan mengenai sengketa; 3) Tahap ketiga, tahap penyelesaian masalah. Selama tahap perundingan penyelesaian problem, mediator membantu para pihak merumuskan permasalahan, menyusun agenda untuk membahas masalah dan mengevaluasi solusi. Pada tahap ketiga ini terkadang mediator mengadakan pertemuan sendiri secara pribadi dengan masing-masing (caucus) pihak secara terpisah, dalam hal ini mediator dapat melakukan tanya jawab secara mendalam untuk memperoleh informasi yang tidak diungkapkan pada suatu kegiatan mediasi bersama. Mediator juga dapat membantu suatu pihak untuk menentukan alternatif dalam menyelesaikannya, mengeksplorasi serta mengevaluasi pilihanpilihan, kepentingan dan kemungkinan penyelesaian secara lebih terbuka. Apabila mediator akan mengadakan caucus, harus menjamin bahwa hal yang mencakup kerahasiaan tidak akan mengungkapkan pada pihak lain, kecuali sudah diberi wewenang untuk itu. Hal ini untuk menjaga netralitas dan memperlakukan yang sama pada para pihak; 4) Tahap keempat, pengambilan keputusan. Dalam tahap ini para pihak saling bekerja sama dengan bantuan mediator untuk memilih solusi yang disepakati bersama atau setidaknya solusi yang dapat diterima terhadap masalah yang diidentifikasi. Setelah mengidentifikasi solusi, para pihak memutuskan sendiri apa yang akan disepakati. Akhirnya para pihak yang sepakat membuat keputusan bersama dituangkan dalam bentuk perjanjian. Mediator membantu untuk menyusun ketentuan yang akan dimuat dalam perjanjian, sehingga dapat mengakomodasi kepentingan para pihak.

Mediasi di luar pengadilan dilaksanakan melalui perdamaian dimohonkan ke pengadilan untuk dikuatkan dalam akta perdamaian. Perjanjian tertulis yang telah disepakati oleh para pihak wajib untuk didaftarkan di pengadilan negeri paling lama 30 hari sejak ditandatangani. ${ }^{51}$ Didaftarkannya kesepakatan tertulis mediasi ke pengadilan negeri, akan memiliki kekuatan eksekutorial, sedangkan kesepakatan perdamaian yang tidak didaftarkan ke pengadilan hanya bersifat perjanjian biasa yang mengikat para pihak berdasarkan Pasal 1338 KUH Perdata "Setiap perjanjian yang dibuat secara sah berlaku sebagai undangundang bagi para pihak yang membuatnya" jo "Asas pacta sunt servanda" (perjanjian harus ditaati). Hal ini berarti kesepakatan tersebut tidak akan mempunyai kekuatan eksekutorial, karena itu penting untuk melakukan

\footnotetext{
51 Pasal 6 Ayat (7) Undang-Undang Nomor 30 Tahun 2009.
} 
pendaftaran kesepakatan sebagaimana diatur dalam Pasal 6 Ayat (7) UU No. 30 Tahun 1999, agar perjanjian perdamaian tersebut memiliki kekuatan hukum, ${ }^{52}$ sehingga lebih mudah untuk dilaksanakan.

\section{Perbandingan}

\begin{tabular}{|c|c|c|c|}
\hline No & Pertimbangan & Arbitrase & Mediasi \\
\hline 1 & Prosedur & $\begin{array}{l}\text { Formal dan } \\
\text { sistematis }\end{array}$ & informal \\
\hline 2 & $\begin{array}{l}\text { Pengatur } \\
\text { proses }\end{array}$ & arbiter & $\begin{array}{l}\text { mediator } \\
\text { yang } \\
\text { dipilih } \\
\text { para pihak }\end{array}$ \\
\hline 3 & Biaya & mahal & murah \\
\hline 4 & $\begin{array}{l}\text { Jangka waktu } \\
\text { pemeriksaan }\end{array}$ & 36 bulan & $\begin{array}{l}\text { tergantung } \\
\text { perdamaian }\end{array}$ \\
\hline 5 & Pembuktian & $\begin{array}{l}\text { agak formal } \\
\text { dan teknis }\end{array}$ & $\begin{array}{l}\text { tidak perlu } \\
\text { formal }\end{array}$ \\
\hline 6 & $\begin{array}{l}\text { Hubungan } \\
\text { para pihak }\end{array}$ & bermusuhan & kooperatif \\
\hline 7 & $\begin{array}{l}\text { Cara } \\
\text { penyelesaian }\end{array}$ & $\begin{array}{l}\text { merujuk } \\
\text { pada hukum } \\
\text { dan } \\
\text { kesepakatan } \\
\text { para pihak }\end{array}$ & kompromis \\
\hline 8 & Suasana & emosional & $\begin{array}{l}\text { meredakan } \\
\text { emosi }\end{array}$ \\
\hline 9 & Publikasi & pribadi & pribadi \\
\hline 10 & $\begin{array}{l}\text { Hasil yang } \\
\text { dicapai }\end{array}$ & $\begin{array}{l}\text { menang- } \\
\text { kalah }\end{array}$ & $\begin{array}{l}\text { sama-sama } \\
\text { menang }\end{array}$ \\
\hline
\end{tabular}

Sumber: https:// core.ac.uk/ download/ files/

$$
\frac{379 / 11723236 . p d f}{\text { dimodifikasi) }} \text { (telah }
$$

Faktor lain, Mediasi sebagai penyelesaian langkah awal, artinya, mediasi tidak menutup kemungkinan untuk mengajukan persengketaan ke pengadilan atau arbitrase. Dalam hal tidak tercapai kompromi, dapat ditingkatkan penyelesaian

\footnotetext{
${ }^{52}$ http://repository.unhas.ac.id/bitstream/handle/123456 789/13835/Skrispi\%20Zulkarnaen\%20Hamka\%20b1 1107950.pdf? sequence $=1$
}

melalui pengadilan. Atau apabila telah tercapai kompromi melalui mediasi, dan salah satu pihak tidak mentaati pemenuhan secara sukarela. Berarti telah terjadi pengingkaran terhadap penyelesaian. Akan tetapi, kalau memperhatikan hasil pengamatan yang dikemukakan Peter Loveheim, kedudukan mediasi sebagai first resort, tidak mengecewakan karena hasil kompromi yang dicapai, selalu ditaati pemenuhannya secara sukarela oleh kedua belah pihak. Menurut Loveheim, dari jumlah sengketa yang diajukan ke mediasi: $85 \%$ berhasil dicapai kompromi, dan hanya $5 \%$ yang tidak ditaati pemenuhan, sehingga terpaksa dilanjutkan penyelesaian ke pengadilan. ${ }^{53}$ Namun, kelemahan itu dapat diatasi dengan cara para pihak sejak semula membuat kesepakatan yang menentukan apabila mediasi gagal mencapai kompromi, mediator langsung bertindak sebagai arbitrator. Melalui klausula kesepakatan yang seperti itu, tidak perlu mengajukan perkara ke pengadilan karena kegagalan mediasi langsung ditampung mediator dan bertindak sebagai arbitrator. ${ }^{54}$

Penyelesaian sengketa mengacu kepada pemikiran bahwa law is a tool of social engineering, ${ }^{55}$ yaitu hukum sebagai alat rekayasa sosial. Pemikiran Max Weber mengenai peran hukum dalam melakukan perubahan terhadap masyarakat dikaji lebih dalam oleh aliran sosiologis (sociological jurisprudence), terutama yang dilakukan Roscoe Pound pada tahun $1912 .{ }^{56}$ Roscoe Pound berpendapat bahwa para ahli hukum yang beraliran sosiologis perlu lebih memperhitungkan fakta-fakta sosial (dalam

\footnotetext{
53 http://www.kesimpulan.com/2009/04/alternatifpenyelesaian-sengketa.html

${ }^{54}$ Ibid.

55 Satjipto Rahardjo, Ilmu Hukum, Alumni, Bandung, 1986. Lihat juga http://saifulanamlaw. blogspot.co.id/ 2013/03/penegakan-hukum-agrariadan.html

${ }^{56}$ Lili Rasjidi dan Ira Rasjidi, Dasar-dasar Filsafat dan Teori Hukum, Citra Aditya Bakti, Bandung, 2001. Hlm. $82 . \quad$ Lihat juga http://saifulanamlaw.blogspot.co.id/2013/03/penegak an-hukum-agraria-dan.html
} 
hal ini terjadinya sengketa) yang ada dalam pekerjaannya, apakah itu merupakan pembuatan hukum, penafsiran atau penerapan aturan-aturan hukum itu sendiri. Para ahli hukum harus mampu secara lebih cerdas memperhitungkan fakta-fakta sosial yang harus diserap dalam hukum dan yang kemudian menjadi sasaran penerapannya (penyelesaian sengketa). Untuk itu, Roscoe Pound menyarankan supaya perhatian lebih terarah pada efek-efek nyata dari institusi dan doktrin hukum, karena kehidupan hukum terletak pada pelaksanaannya. Agar hukum dapat lebih memenuhi kebutuhan masyarakat, kondisi-kondisi social yang paling mutakhir perlu diperhatikan, seperti latar belakang terjadinya sengketa. Dengan mengakomodasi perkembangan terakhir dari fakta-fakta social dalam arti kebutuhan, kepentingan dan aspirasi masyarakat, fungsi hukum sebagai social engineering dalam menyelesaiakan sengketa akan lebih transformatif.

Konsep hukum sebagai sarana pembaharuan dan pembangunan masyarakat didasarkan pada konsep law as a tool of social engineering yang tumbuh pada mazhab sociological jurisprudence, yang dipelopori antara lain oleh Roscoe Pound, Eugen Ehrlich, Benyamin Cardozo, Kantorowics, Gurvitch. Dalam konsep hukum sebagai sarana pembaharuan ini, penekanan lebih condong kepada peraturan perundangundangan, yaitu hukum yang baik adalah hukum yang sesuai dengan hukum yang hidup di dalam masyarakat (living law). ${ }^{57}$ Apabila konsep hukum sebagai sarana pembaharuan dan pembangunan masyarakat dikaitkan dengan penyelesaian sengketa, maka arbiter atau mediator, melalui keputusannya seharusnya merupakan media untuk menciptakan ketertiban dibidang KI. Oleh karena itu, penegakan hukum KI berkaitan dengan penyelesaian sengketa non litigasi harus memberikan keseimbangan dalam mewujudkan prinsip keadilan dan kepastian hukum terhadap para pihak yang bersengketa.
Berkaitan dengan eksistensi BAM KI, seharusnya badan ini berfungsi dengan baik untuk menyelesaikan sengketa secara spesifik di bidang KI. Penyelesaian sengketa yang ditangani secara khusus oleh badan tertentu lebih menjamin tingkat efektivitas dan efisiensi dari dari biaya, waktu dan tenaga serta keakuratan putusan karena ditangani oleh para expert di bidang hukum KI. Namun, fakta sosial sebagaimana dikemukakan oleh aliran sociological jurisprudence, yaitu belum tertariknya para pihak yang bersengketa untuk menyelesaian melalui badan yang telah dibentuk tersebut merupakan tantangan yang harus dihadapi agar pelaku bisnis bersedia memanfaatkan sarana yang telah disediakan, sehingga keberadaan BAM KI yang juga harus diberikan landasan hukumnya dapat menjadi sarana perubahan masyarakat untuk menjadikan badan ini sebagai "tumpuan dan harapan" dalam menyelesaian sengketa KI, sebagaimana ajaran law as a tool of social engineering yang dimodifikasi oleh Mochtar Kusumaatmadja " hukum sebagai sarana perubahan sosial masyarakat."

\section{PENUTUP}

Simpulan :

a. Penyelesaian sengketa KI melalui Arbitrase dan Mediasi masing-masing memiliki kelebihan dan kelemahan. Mediasi lebih efektif dan efisien dibandingkan Arbitrase berkaitan dengan hubungan para pihak, suasana, hasil yang dicapai, dan biaya. Namun dari sisi kepastian hukum, arbitrase lebih efektif karena putusannya bersifat final and binding.

b. Untuk Penyelesaian sengketa KI secara spesifik sudah dibentuk Badan khusus yaitu BAM KI, tetapi kenyataannya para pelaku usaha belum memanfaatkan fungsi badan tersebut secara maksimal, sehingga eksistensi BAM KI belum berjalan efektif. 
Rekomendasi:

a. UU No. 30 Tahun 1999 perlu segera direvisi, alternatif yang dapat direkomendasikan adalah (1) judulnya "UU Alternatif Penyelesaian Sengketa" karena Arbitrase pada hakekatnya termasuk Alternatif Penyelesaian Sengketa, tetapi ketentuan tentang caracara Alternatif Penyelesaian Sengketa perlu diatur secara seimbang; (2) judulnya "UU Arbitrase" tetapi perlu menghilangkan ketentuan yang mengatur ADR yaitu Pasal 1 butir (10) dan Pasal 6, sedangkan ketentuan ADR dibuat secara suigeneris ( UU tersendiri), atau apabila UU tersebut tetap berjudul "UU Arbitrase dan Alternatif Penyelesaian Sengketa", maka substansi pengaturannya keduanya harus proporsional karena pada saat ini UU No 30 Tahun 1999 mengatur Tentang Arbitrase meliputi 80 pasal, sedangkan ketentuan mengenai ADR hanya dalam 2 pasal saja, yaitu dalam Pasal 1 butir (10), dan Pasal 6 yang terdiri dari 9 ayat.

b. Perlu sosialisasi tentang keberadaan dan fungsi BAM KI agar pelaku bisnis tertarik untuk menyelesaikan sengketa KI melalui badan tersebut, tetapi perlu juga diberikan landasan hukumnya dengan cara mencantumkan BAM KI sebagai pilihan forum (chooice of forum) melalui ketentuan dalam UU KI yang bersangkutan.

\section{DAFTAR PUSTAKA}

\section{Buku}

Fuady, Munir. Arbitrase Nasional (Alternatif Penyelesaian Sengketa Bisnis).

Bandung: Citra Aditya Bakti, 2003. Pengantar Hukum Bisnis: Menata Bisnis Modern di Era Global. Bandung: Citra Aditya Bakti, 2005.

HS, Salim. Perkembangan Teori Dalam Ilmu Hukum, Raja Grafindo Persada. Jakarta: 2010.
Sutiyoso, Bambang, Hukum Arbitrase Dan Alternatif Penyelesaian Sengketa. Yogyakarta : Gama Media, 2008.

Goodpaster Garry. Tinjauan Terhadap Penyelesaian Sengketa. Jakarta : Ghalia Indonesia, 1995.

Soemartono, Gatot. Persoalan Pilihan-pilihan Pengadilan, Hukum, dan Arbitrase Dalam Penyelesaian Sengketa Bisnis Internasional. Jakarta : PT Gramedia Pustaka Utama, 2006.

Raiffa, Howard. The Art and Science of Negotiation. Masschusetts : Harvard University Press, 1982.

Wiryawa, I Wayan \& I Ketut Artadi, Penyelesaian Sengketa Di Luar Pengadilan. Denpasar -Bali : Udayana University Press, 2010.

Achmad, Santoso Mas. Mekanisme Penyelesaian Sengketa Lingkungan Secara Kooperatif (Alternative Dispute esolution/ ADR). Jakarta : Indonesian Center for Environment Law, 1995.

Shofie, Yusuf. Penyelesaian Sengketa Konsumen Menurut UUPK Teori dan Praktik

Penegakan Hukum. Bandung : PT Citra Aditya Bakti, 2003.

Soekanto, Soerjono dan Sri Mamudji, Penelitian Hukum Normatif : Suatu Tinjauan Singkat, Jakarta: PT RajaGrafindo Persada, 2004.

\section{Perundang-undangan}

Republik Indonesia, Undang-undang Nomor UU No 13 Tahun 2016 Tentang Paten.

Republik Indonesia, Undang-undang Nomor No 20 Tahun 2016 Tentang Merek dan Indikasi Geografis.

Republik Indonesia, Undang-undang Nomor UU No. 28 Tahun 2014.

Republik Indonesia, Undang-undang Nomor No 29 Tahun 2000 Tentang Perlindungan Varietas Tanaman. 
Republik Indonesia, Undang-undang Nomor UU No 30 Tahun 2000 Rahasia Dagang

Republik Indonesia, Undang-undang No 31 Tahun 2000 Tentang Desain Industri.

Republik Indonesia, Undang-undang Nomor 32 Tahun 2000Desain Tata Letak Sirkuit Terpadu.

Republik Indonesia, Undang-undang Nomor. 30 Tahun 1999 Tentang Arbitrase dan Alternatif Penyelesaian Sengketa.

\section{Jurnal dan makalah dan Penerbitan lainnya \\ Abdurrasyid, Priyatna. Penyelesaian Sengketa Perdagangan Internasional Di Luar Pengadilan, Makalah Seminar Nasional Hukum Bisnis. Salatiga: Fakultas Hukum UKSW, 1996. \\ Badan Arbitrase Nasional Indonesia, Rules and Prosedure. \\ Halim Barkatullah, Abdul "Bentuk Perlindungan Hukum Bagi Konsumen Dalam Penyelesaian Sengketa Transaksi Elektronik Internasional Menurut UU No. 11 Tahun 2008". Jakarta : Jurnal Hukum Bisnis, Vol. 29 No. 1, (2010).}

\section{Kamus}

Black, Henry Campbell, Black's Law Dictonary. West Publishing Co., St. Paul, 1979.

Marwan, M , dan Jimmy P, Kamus Hukum.: Surabaya: Reality Publisher, 2009.

\section{Sumber lainnya}

hukum.on line. Penyelesaian Sengketa HaKI Lewat Pengadilan Niaga. http://www.hukumonline.com/berita/b aca/hol2186/ (Diakses, 2 Juli, 2017). 